\title{
Green Party Members and Grassroots Democracy: A Comparative Analysis
}

\author{
Wolfgang Rüdig \\ School of Government and Public Policy \\ University of Strathclyde \\ and \\ Javier Sajuria \\ School of Politics and International Relations \\ Queen Mary, University of London
}

September 2017 


\begin{abstract}
(142 words)
When green parties emerged in the 1970s and 1980s, their political project included a strong commitment to a new type of internal party organisation, giving power to the 'grassroots'. With Green parties having become well-established in most West European party systems, has the vision of 'grassroots democracy' survived the party foundation stage? What drives the ongoing or waning commitment to grassroots democracy? Analysing party membership survey data from 15 parties collected in the early 2000s when many green parties had for the first time become involved in national government, we find that it is the social movement oriented, pacifist, left-wing membership that is most committed to grassroots democracy. It is the current involvement in social movements rather than past activity that is most important. Support for grassroots democracy is also stronger in "Latin Europe" and Greece but weaker in parties which have become established in parliament and government.
\end{abstract}




\section{Introduction ${ }^{1}$}

The study of intra-party democracy has been one of the perennial themes of the political sociology of political parties. After the classical studies of Ostrogorski (1902) and Michels (1911), however, the achievement of internal party democracy seemed to constitute a utopian dream. Later analyses went further claiming a contradiction between internal party democracy and a party's political effectiveness (Duverger 1964, p. 134) and even an incompatibility with democratic government (McKenzie 1982, p. 195).

This academic rejection of the concept of internal party democracy has more recently given way to a growing literature that examines a range of organisational features empirically (cf. Poguntke et al. 2016). The starting point for this renewed interest in questions of party organisation appears to have been the introduction of plebiscitary elements in some Western European parties in the 1990s (Scarrow 1999; Seyd 1999). While the exact implications of these recent reforms for the nature of party democracy are still to unravel, they follow on from an earlier development to challenge the dominant philosophy of party organisation which has not attracted a lot of systematic attention: the attempt to introduce 'grassroots democracy' in green parties.

More than any other parties, green parties have been associated with the endeavour to relaunch the idea of internal party democracy. Rejection of established parties and their way of operating was an essential part of the political context in which green parties emerged in the 1970s and 1980s. The new parties sought to put into practice an idea borrowed from the agenda of the new social movements. The hierarchical nature of established parties and their non-responsiveness to demands made by ordinary citizens 
(including party members) had to be overcome by creating a 'new type of politics'. For the new green parties, this meant the introduction of 'grassroots democracy', with the emphasis on giving power to ordinary members rather than party leaders or a party elite.

Their attempt to create a 'new politics' with a commitment to participatory democracy and rejection of traditional party politics attracted some considerable attention in the $1980 \mathrm{~s}$ when green parties first managed to enter national parliaments in most West European countries. The concept of grassroots democracy was arguably not well defined. It was, first of all, a rejection of established party politics, and how exactly to give power to the 'grassroots' remained an issue of contention within green parties (cf. Heinrich 1993; Sarkar 1994). New concepts such as the 'rotation' of public offices and term limitations for party positions were introduced. Holding public and party offices was widely seen as incompatible. Perhaps most visibly, green parties rejected the hierarchical nature of established parties and the concept of 'party leadership', opting instead for decisions to be made by the 'grassroots' and a collective approach of representing the party to the outside world. While some early ideas, such as a the 'rotation' of offices, were fairly quickly abandoned and many green parties went through a number of organisational reforms, the agenda of giving the grassroots a significant role was generally retained, giving contemporary green parties a 'distinctive organisational style' (Rihoux 2016, 299).

Two broad interpretations of the grassroots democracy phenomenon in green parties have emerged. The first is influenced by the idea of political parties following a standard development path of parties which was first outlined by Robert Michels (1911) and later became a key element of other classical theories, for example Panebianco's theory of party institutionalisation (Panebianco 1988). This strand of argument sees green parties passing 
through different development passes that eventually will see them, or at least the successful green parties, embracing essentially the same organisational principles and practices that established parties have adopted. With the 'social movement' character of green parties disappearing and having to meet the demands of parliamentary politics, and more recently, of governmental participation, green parties are seen as forced to reorganise (or 'modernise') their internal structures if they want to survive, requiring a rejection of major elements of grassroots democracy. In the literature of green parties, the need for green parties to follow such a path and 'modernise' has been strongly articulated in national case studies, in particular of the German Greens (e.g. Raschke 2001; Bukow and Rammelt 2003; Blühdorn and Szarka 2004).

The alternative view challenges such a linear model that ties specific organisational principles to particular development phases. Comparative studies of the development of green party organisation have shed doubts on the view that parliamentary and governmental responsibilities are intrinsically linked to specific organisational reforms (Rihoux 2001). This would suggest a 'party family' (Mair and Mudde 1998) model of green party organisation. While this leaves open the possibility that grassroots democracy is not just a characteristic of the early development of green parties but will survive as an essential element of green political identity, it raises the question of how embedded the concept of grassroots democracy is within green parties.

Most previous studies of green party organisations have focused on the analysis of party debates and observed changes over time as well as differences between countries (Rihoux 2001, 2006, 2016; Burchell 2001, 2002; Frankland et al. 2008; Miragliotta 2015). One aspect that has not been studied recently is the views of green party members on questions 
of green party organisations. Within the empirical literature on party members, the analysis of members' attitudes to specific organisational principles is relatively rare (but cf. Young and Cross 2002; Hansen and Saglie 2005). For green parties, party members are obviously crucial for any concept of grassroots democracy. We seek to explore to what extent grassroots democracy is supported by party members and what factors determine attitudes to internal party democracy in green parties.

Herbert Kitschelt's path-breaking work on the internal dynamics of the German and Belgian green parties in the 1980s, based on extensive interviews as well as membership surveys, is an obvious starting point for such an endeavour (Kitschelt 1988, 1989, 1990; Kitschelt and Hellemans 1990). The field work for these studies was undertaken some time ago in the early years of green party development. Since then, many green parties in Western Europe have established themselves in the political system. Looking at the organisational level of green parties, the main changes involving a certain movement away from some of the more extreme elements of grassroots democracy could be observed during the late 1980s and 1990s (Rihoux 2001). Between the early 2000s and the present, there have been some incremental changes but key elements of the internal structure of green parties remain in place and questions of party organisation have not dominated internal party debate to the extent this could be observed in earlier years (Rihoux 2016).

Apart from exploring the sources of support for grassroots principles at the individual level, a key question is the impact of contextual factors. One might expect that certain aspects of political socialization and values held would increase the potential of support for grassroots democracy, but it is uncertain whether this applies to the same degree depending on the kind of political context in which green parties find themselves. In particular, we 
have to ask whether it makes a difference whether a party is at the margins of politics or has risen to political relevance. Also from that perspective, the timing of the survey is particularly useful. By the early 2000s, there was some considerable variation in the development stages reached by green parties. Some green parties, for example in Greece and Norway, were extremely marginal and were not seen as having a realistic chance of winning parliamentary representation at national level. At the other extreme, several green parties had for the first time entered coalition government at national level in the late 1990s. This provides a unique opportunity to test for the import of development stages.

This paper seeks to contribute to the study of intra-party democracy by analysing the attitudes of green party members to grassroots democracy in the early 2000s. The chief data source for this study is an extensive comparative survey of green party members, covering 18 parties in 15 countries, undertaken in 2002 and $2003 .^{2}$

\section{Theory and Hypotheses}

The historical analyses of the formation and early development of green parties identify a range of pertinent factors that led to these parties taking up grassroots democracy: these were parties emerging from the 'new' social movements of the 1960s, 1970s and 1980s, with a constituency strongly influenced by the values of the 'New Left' (e.g. MüllerRommel 1989; Parkin 1989; Richardson and Rootes 1995; O’Neill 1997). While there are many political factors that contributed to green parties placing a strong emphasis on a rejection of party hierarchy and the establishment of a 'truly' democratic party, the 
influence of the experience of the 'new social movements', in conjunction with a 'libertarian' left outlook within a broadly 'anarchist' framework, played a dominant role (Kitschelt 1988, p. 129, p. 134; Doherty and Geus 1996, p. 5; Hay 2002, pp. 277-282).

This would lead us to expect, first, that Green Party members who have been active in 'new social movements' should be more supportive of grassroots democracy than those without such an experience. The effect could be expected to be stronger among members who were engaged in social movement activity at the time of the survey. The antiglobalisation movement was arguably the main contemporary social movement at the time which had a strong anti-hierarchical, anarchist ideology (el-Ojeili 2014), which might thus particularly lend itself to views sympathetic to grassroots democracy.

H1. Members with a strong past involvement in social movements are more supportive of grassroots democracy.

H2. Members who are currently involved in social movement activity are more likely to support grassroots democracy.

Moving on to questions of political attitudes, the literature referred to would suggest that Green Party members embracing more 'left-wing' political views should be more amenable to the ideas of grassroots democracy. Furthermore, one might expect members who continue to support the key demands of the new social movements most closely associated with green parties during their foundation phase to be more supportive of grassroots democracy. We have a range of possible variables to consider here, ${ }^{3}$ but we 
chose to concentrate on two key indicators important for green politics in the early 1980s: left-wing attitudes and pacifism.

H3. Members aligned with the 'Left' are more likely to support grassroots democracy.

H4. Members with strong pacifist views are more likely to support grassroots democracy.

If we follow Kitschelt's writings on the German and Belgian green parties in the 1980s (Kitschelt 1989; Kitschelt and Hellemans 1990), then activists with a strong commitment to grassroots democracy should be those restricting their activity to party activity, taking little or no interest in obtaining public office. Party 'busybodies' know the rules of the game best and can use them to their advantage, which often means trying to challenge the dominance of parliamentary parties and reasserting the rights of party activists to keep office holders under control. Holders of public office, on the other hand, could be expected to be more sceptical about grassroots democracy as its use undermines rather than supports their position.

H5. Party office holders are more likely to support grassroots democracy principles while public office holders are more likely to oppose them.

Having looked at these individual-level determinants of support for grassroots democracy, we finally turn to the possible impact of contextual factors. One major reference point is 
the theory of a standard development path as advanced by Michels (1911) and Panebianco (1988). We use the party life-span model first developed by Pedersen $(1982,1991)$ to distinguish between distinct phases of party development determined by thresholds they have to overcome (cf. also Müller-Rommel 2002). Different thresholds might make different types of demand on parties. At first, parties have to generate public support in order to register and make it onto the ballot paper; forming broad coalitions of people willing to support the party is here crucial. Once a party is formally constituted and admitted to the electoral process, the party will want to take the next threshold, that of electoral representation. Once this threshold is taken, the focus of the party should switch to the participation in the political process; the parliamentary party is likely to become an important focus. Making an effort to become 'relevant' in terms of government formation may be a turning point as the focus of the party may switch from membership mobilisation and representation to being represented in the media in a certain way to underline its suitability as a coalition partner; this having been successfully accomplished, the actual joining of a government coalition is likely to impose further burdens on the party as compromises to stay in power have to be 'sold' to the party and the membership at large.

What we might expect is that the more advanced a green party is along this path, the less likely party members are interested in maintaining principles of grassroots democracy. Instead, the party should become dominated by the need to attract electoral support and to achieve and maintain credibility as a partner in government. In Kitschelt's terminology, the focus of green parties should change from a 'logic of constituency representation' to a 'logic of party competition' (Kitschelt 1988, p. 129). The pressures of parliamentary and governmental politics should provide a greater challenge to green party members to confront their traditional commitment to grassroots democracy, strengthening views that 
green parties have to 'modernise' in order to be more effective in terms of electoral competition and being considered a trustworthy partner in government.

H6. The further a green party has progressed along the party 'life span' model, the lower the support for grassroots democracy.

\section{Data and Methodology}

The analysis presented in this paper is based on a unique set of comparative data that has been collected by the 'European Green Party Membership' project funded by the British Academy. ${ }^{4}$ A research group with members in most West European countries met for the first time in 2001 to agree on a common core-questionnaire that was fielded during 2002 and 2003 in 15 countries. A total of 18 parties agreed to be part of the project. Details of the fieldwork are documented in Appendix 1.

To our knowledge, no survey of party members has tried to measure support for grassroots democracy. ${ }^{5}$ We thus had to develop our own instruments to reflect the state of the discourses on grassroots democracy in the early 2000s. The danger we faced was that indicators of grassroots democracy could be culturally tied to specific national contexts. Poguntke in his discussion of the principles of 'Basisdemokratie' in the German Greens gives a long list of very different elements of party organisation (Poguntke 1993, pp. 136171), some of which are closely tied to the specifics of the German political culture. At the other extreme, attitudes to abstract theoretical principles as discussed by political theorists (e.g. Doherty and de Geus 1996) do not lend themselves easily to survey research. 
After detailed discussions, ${ }^{6}$ the research group decided on a number of questions aiming to confront members with statements that established important principles but were specific enough to elicit responses also from those not familiar with abstract green principles. In order to create the dependent variable, we concentrated on four elements that are closely related to key elements defining grassroots democracy within a comparative context, as recently outlined by Rihoux (2016).

First, the issue of collective leadership had been an element of high 'symbolic' importance to many parties that sought to emphasize a break with traditional party politics. Most green parties thus started out rejecting the idea of the party being 'led' by a single leader, and opted for some form of collective leadership. However, by the early 2000s, some parties had adopted the concept of a single leader. The first element of the dependent variable consists on attitudes towards a 'single leader' (for details on the construction of the dependent variable, see Appendix 2).

In addition to the leadership issue, we developed - and added to the dependent variable - a battery of questions that included other measurements of grassroots democracy. These questions consisted on 1-5 agreement scales with a series of statements. The key element of the green debates of the 1980s and 1990s had been to avoid the formation of a party elite, or at least limit its powers. Measures were thus discussed (and introduced in many cases) that imposed restrictions on what party elites could do.

The first of these elements relates to term limits for party offices. Most green parties also included limitations to combine public and party offices, and this statement has been tested in the questionnaire. Finally, elected representatives were also expected to contribute a 
substantial part of their salary to party funds. ${ }^{7}$ The wording of all questions used for the analysis is documented in Appendix 2 and the responses to the individual questions are documented in Appendix 3.

The question we need to ask is whether these four principles derived from the international history of green party debates about key issue of party organisation, including the question on a 'single leader', are actually measuring the same latent phenomenon: grassroots democracy may be a concept known to academic students of green politics and long-term activists, but ordinary party members may not necessarily interpret questions about individual items of party organisation in that way. Also, there is the question whether grassroots democracy is essentially a unidimensional phenomenon.

A number of tests were conducted to shed light on these questions. Factor analyses were conducted for the international dataset and each national study: they revealed little or no evidence of multi-dimensionality. In most countries, the factor analysis only produced one valid factor, a second factor fell just below the margin of the Eigenvalue.$\geq 1$ criterion. In only a handful of countries, this second factor just passed the margin of 1 . All four variables are inter-correlated, although not quite as strongly and consistently as one might have expected. However, the case to form one scale for the measurement of attachment to grassroots democracy is essentially based on considerations of the substance of green politics: these four statements historically stand for key principles of grassroots democracy. The degree to which they all are representing the same principle by party members is a question to be explored. 
A number of options were explored to construct a dependent variable combining all four elements. These included the construction of various additive indexes. In the end, the factor scores provided the best option. Given the heterogeneity of the data, all multivariate analyses were run with different formats of the dependent variable, as well as on each question individually, but the results did not vary to any significant degree, suggesting that our results are robust.

The operationalisation of individual-level variables follows well established procedures, but the definition of the party-level variable may require some explanation. In order to distinguish different parts of the party 'lifespan', as inspired by the work of Mogens Pedersen, green parties were allocated to four different groups according to their progress. Parties not having achieved parliamentary representation (at national level) were distinguished from parties that had entered parliament but were not considered 'relevant' in terms of government formation. A further distinction was made between 'relevant' parties that had not attained a role in national government and parties that had entered government coalitions at national level. The effect of party lifespan position on grassroots democracy is to be examined with the help of a multi-level model.

Of crucial importance was the inclusion of control variables. For individual level predictors, we included age and gender. Age here is particularly important as a control for historical social movement activity as older members would obviously had more opportunities to become involved in various social movement activities.

The inclusion of control variables at the contextual level proved particularly challenging. Given the relatively small number of parties included (15), it was important to specify a 
parsimonious model that would allow us to control effectively for the variation between countries while, at the same time, observe the relevant differences in our variables of interest. ${ }^{8}$ Looking at the results on the cross-national differences in support for grassroots democracy (see Appendix 3), it became obvious that support was much higher in Southern European countries (Greece, Italy, Spain) but also in France and the French-speaking part of Belgium. These parties were at very different stages in the party 'lifespan' model. What, apart from representing 'Latin Europe' (apart from Greece), do these countries have in common? Looking at indicators such as trust in political parties, interpersonal trust, and also perception of corruption, there was a clear difference between "Latin" countries and Greece on the one hand and Northern European countries on the other (European Commission 2002; ESS Round 1: European Social Survey Round 1 Data (2002); Transparency International 2002; Inglehart et al. 2004, p. A165). These differences also manifested themselves within countries: trust in political parties was substantially higher among the Flemish speaking and lower among the French speaking population of Belgium. A detailed analysis of the historical development of organisational structures of green parties in Belgium suggests that, unlike members of their Flemish sister party, ECOLO members 'still have a tradition of lack of confidence in their representatives and professionals' (Buelens and Delwit 2008, p. 90). This is despite the fact that, historically, the Flemish Greens had a higher degree of involvement with social movements ${ }^{9}$, suggesting broader cultural differences may be responsible.

The exact nature of the reasons why members of green parties in Latin Europe and Greece have a more positive attitude to grassroots democracy will require some further detailed analysis which goes beyond this paper. For our model, this raises two questions which we can answer: are the individual level predictors different for parties in Northern and 
Southern Europe, and how does this factor impact on the relation between party lifespan position and attitudes to grassroots democracy? In order to answer these questions, we thus decided to create a simple dummy variable, distinguishing between 'Latin' and Greek countries on the one hand and Northern European countries on the other, to be used a control variable in the model.

\section{Results}

In order to test our hypotheses, we conducted a number of multivariate analyses whose results are displayed in Table 1 . The first model is a standard ordinary least square regression model which includes all independent variables at the individual level. The second model presents the result of a multi-level analysis where we allow for varying intercepts by party, including the party-level type predictors.

--- Table 1 about here ---

The first important result concerns the influence of social movement activity. Our analysis suggests that social movement activities before and during the formation phase of green politics have no impact on attachment to grassroots democracy: those members who had been student, anti-nuclear and peace activists in the 1960s, 1970s and 1980s were not more likely to support grassroots democracy than others. Given the strong historical link, this finding is perhaps surprising. It appears that social movement experience does not have a sustained impact on the attitudes of participants, at least not as far as attitudes to grassroots democracy are concerned. H1 is thus not confirmed. 
What did make a difference was the recent involvement in social movement activity that appeared to be most strongly related to support for grassroots democracy. Contemporary social movement activists who also joined green parties are thus more open to the idea of grassroots democracy, and thus $\mathrm{H} 2$ could be confirmed. However, we need to be careful here in terms of inferring any direct of causal sequence. In the absence of panel data, we cannot really distinguish whether green party members who support grassroots democracy are more likely to go out and also become active outside of party politics, or whether social movement activists bring preferences about internal organisation with them from the social movements into green parties.

What can be said, however, is that a strong history of social movement activity does not translate into enduring preferences for grassroots democracy. This seems to suggest that the call for strong internal party democracy is maintained by continuous social movement engagement. A discontinuity of such engagement may thus make it more difficult for green party activists to maintain a strong focus on preserving the idea of grassroots democracy.

Moving on to questions of ideology, here the coefficients clearly suggest that members placing them on the left of the left-right scale and those who have strong pacifist attitudes are more likely to be supportive of grassroots democracy. H3 and H4 can thus clearly be confirmed.

Turning to questions of the effect of holding office in the party, our results provide at least partial confirmation for H5. Holders of public office are less enthusiastic about grassroots 
democracy. Holders of party offices have a tendency to go into the opposite direction, although the co-efficient is not significant.

Overall, the individual level model broadly confirms our hypotheses: support for grassroots democracy is driven by left-wing, pacifist members who are currently active in social movements and do not hold a public office. The results are fairly robust as they apply across the board and across countries fairly consistently. The regression coefficients do not change fundamentally once party-level variables are included in the second, multi-level model.

The two party-level variables that are part of the model are Latin/Greek political culture and political lifespan. Support for grassroots democracy is clearly more widespread in Greece, Italy, Spain, France and the French-speaking parts of Belgium. This divide is quite stark, and it cannot therefore surprise that this variable is a statistically significant predictor of support for grassroots democracy.

This effect has to be seen together with the lifespan variable. Contrasting parties that have entered parliament, have become a relevant force in the political system and have entered national coalition government with parties that have been not had much success and are still struggling to establish themselves shows that parties in the latter parts of the development tend to be less likely to support grassroots democracy. It is noteworthy that, at the bivariate level, it seemed that there is no statistically significant correlation here but once the preponderance of pro-democracy views within the French and Italian green parties that experienced government at the time of the survey is taking account of, the lifespan model seems to work, and H6 is thus confirmed. 
---- Figure 1 about here ---

In Figure 1, we plot the predicted values for different types of green parties along the various party 'lifespan' phases. In order to estimate the uncertainty of the predictions, we rely on pseudo-Bayesian simulations, while keeping all the other variables at their means or modal categories. What becomes clear here is that the difference between the attitudes of party members to grassroots democracy are not very strong at different development stages. Once parties enter 'mainstream' politics, preferences change, but moving further ahead on the 'lifespan' path does not appear to have a major impact.

\section{Conclusions}

Even after more than 20 years of green party development, the main forces behind demands for grassroots democracy in green parties are still the same: it is the social movement oriented, pacifist membership identifying with the political Left that is pushing for grassroots democracy. However, we found no evidence that past involvement in social movements that were of key importance to green parties in their formative phase, such as the student, anti-nuclear and peace movements, is positively associated with support for grassroots democracy. Support for grassroots democracy in green parties does not involve green 'oldies' harking back to the good old times of social movement politics. What makes a contribution is current involvement in protest politics. Social movements thus continue to play a role in influencing the organisational agenda in green politics. 
We have to be careful, of course, about the direction of any causal links claimed. The history of green parties sees social movement activities preceding green party formation. We thus can be fairly confident that key social movement experiences, particularly in the 1960s and 1970s, preceded green party activity, and thus we have a possible causal sequence here that starts with social movements and influences attitudes to grassroots democracy within green parties. As we found, there is actually no link between past social movement activity and support for grassroots democracy. For the 2000s, however, the nature of the causal sequence is not so clear. It is possible that members engaged in social movement activities in the 2000s were drawn into the party, thus establishing a causal sequence starting with the social movement experience. On the other hand, it is equally possible that green party members holding certain views on internal party democracy were more likely to engage in social movement activities. In any case, the association of contemporary social movement activity and support for grassroots democracy does suggest that on-going social movement activity is an important element. This would suggest that support for grassroots democracy is thus likely to decline in the context of an absence of any strong social movement mobilisation, but that it may revive in the context of new social movements emerging.

Equally, the association between pacifist beliefs and left-wing orientation and support for grassroots democracy suggests that changes in the ideological make-up of parties may have an important influence on attitudes to internal party democracy. However, this does not necessarily suggest that all parties will follow the same development model. Some green parties may move away from radical positions and adjust their internal structure accordingly. Other parties may be re-energised by new social movement involvement and move from more moderate to more left-wing positions. The contrasting recent 
development of the English and German Greens provides a case in point. It will be interesting to examine attitudes to grassroots democracy over time to examine these questions further.

Also the results on the influence of party 'lifespan' on attitudes to grassroots democracy does not fully support the notion of a simple development path from 'movement' to 'normal' parties. Green parties do not abandon all notions of grassroots democracy once they enter parliament or become part of national government. Our results suggest that while members of 'outsider' parties not able to enter parliament are somewhat more likely to embrace grassroots democracy, there is very little difference between further steps on the lifespan model. Other forces must be at work here. Looking at the strength of support for grassroots democracy across countries, a clear North-South divide is apparent, with members of green parties in 'Latin Europe' and Greece displaying rather more support for grassroots democracy irrespective of their party's development phase. The exact reasons for this finding are somewhat unclear. Some of these countries, in particular Greece, Spain, Italy and France, have a well-developed protest culture which may more readily feed into green parties' ideas associated with grassroots democracy. Another element which might be worth exploring is the influence of anarchist thinking. Preferences for participatory democracy in general could, indeed, be seen primarily as part of the anarchist political philosophy (Barber 1984). Anarchist thinking has historically had a strong influence in left-wing political discourses in some European countries, for example in Spain, France and Italy. Apart from the influence of social movements, different traditions of left-wing politics might thus have an influence here on cross-national differences in the attitudes of green party members. 
Looking forward, what are the implications of our findings for the future research agenda? First, the question of grassroots democracy still is of topical importance. Looking at developments since the early 2000s, green parties clearly display a continued commitment to grassroots democracy (Rihoux 2016). Green parties thus maintain organisational structures that display some continuing commitment to the values of the party formation phase. What is required, though, is to analyse party members' attitudes not only in a crossnational but also cross-temporal setting to come to a better understanding of the drivers of support and rejection of principles of grassroots democracy over time.

Second, while the green 'model' of grassroots democracy endures as part of the green party project, it does not appear to have been adopted by any other party family, and thus the wider green project of changing the nature of party politics more widely has clearly failed (Rihoux and Frankland 2008, p. 284). Green parties are, however, facing a new challenge to their philosophy of internal party democracy from other parties in the shape of plebiscitary elements of internal party organisation. Poguntke et al. (2016) make a distinction between 'assembly based intra-party democracy' (AIDP) and 'plebiscitary intra-party democracy' (PIPD). The green party model clearly fits the AIDP model. According to their cross-national analysis of party constitutions, green parties come out rather well on the AIPD score which is higher than that of all other party families. However, in terms of their PIPD score, green parties are merely average and have a lower score than Social Democratic and Liberal parties (Poguntke et al. 2016, p. 672). It will be one of the challenges for green parties how their self-perception as parties with a very high level of intra-party democracy can be reconciled with their apparent reluctance to embrace the introduction of plebiscitary forms of decision making. The attitudes of members here 
might be quite important, and it would be interesting to see what drives attitudes of green party members to 'plebiscitary' measures. 


\section{References}

Barber B R (1984) Strong Democracy: Participatory Politics for a New Age. Berkeley, CA: University of California Press.

Blühdorn, I and Szarka J. (2004). Managing strategic positioning choices. A reappraisal of the development paths of the French and German green parties Journal of Contemporary European Studies 12(3): 303-319.

Buelens J and Delwit P. (2008) Belgium: Ecolo and Agalev (Groen!): Two institutionalized green parties with parallel but different stories. In: Frankland EG Lucardie P and Rihoux B (eds) Green Parties in Transition: The End of Grass-roots Democracy? Farnham, Surrey: Ashgate, pp. 75-91.

Bukow S and Rammelt S. (2003) Parteimanagement vor neuen Herausforderungen. Münster: LIT-Verlag.

Burchell J (2001) Evolving or conforming? Assessing organisational reform within European green parties West European Politics, 24 (3): 113-134.

Burchell J (2002) The Evolution of Green Politics: Development and Change within European Green Parties. London: Earthscan.

Doherty B and de Geus M (1996) Introduction In: Doherty B and de Geus M (eds) Democracy and Green Political Thought. London: Routledge, pp. 1-15. 
Dunlap RE and van Liere K. (1978) The "new environmental paradigm": A proposed measuring instrument and preliminary results Journal of Environmental Education 9 (4): $10-19$.

Duverger M (1964) Political Parties, $3^{\text {rd }}$ ed. London: Methuen.

el-Ojeili C (2014) Anarchism as the contemporary spirit of anti-capitalism? A critical survey of recent debates Critical Sociology 40 (3): 451-468.

ESS Round 1: European Social Survey Round 1 Data (2002). Data file edition 6.5. NSD Norwegian Centre for Research Data, Norway - Data Archive and distributor of ESS data for ESS ERIC.

European Commission (2012). Eurobarometer 57.1 (Mar-May 2002). European Opinion Research Group (EORG), Brussels. GESIS Data Archive, Cologne. ZA3639 Data file Version 1.0.1, doi:10.4232/1.10949

Frankland, EG Lucardie P and Rihoux B (eds) (2008) Green Parties in Transition:The End of Grass-roots Democracy? Farnham, Surrey: Ashgate.

Hansen B and Saglie J (2005) Who should govern political parties? Organizational values in Norwegian and Danish political parties. Scandinavian Political Studies 28 (1): 1-23. 
Hay P (2002) Main Currents in Western Environmental Thought. Bloomington, IN: Indiana University Press.

Heinrich G (1993) Basisdemokratie (Regelungen und Revisionen). In: Raschke J, Die Grünen. Wie sie wurden, was sie sind. Cologne: Bund-Verlag, pp. 488-498.

Inglehart R (1977) The Silent Revolution: Changing Values and Political Styles in Western Europe. Princeton, N.J.: Princeton University Press.

Inglehart R (1990) Culture Shift in Advanced Industrial Society. Princeton, N.J.: Princeton University Press.

Inglehart R Basáñez M Díez-Medrano J Halman L and Luijkx R (eds)(2004) Human Beliefs and Values: A Cross-Cultural Sourcebook based on the 1999-2002 Values Surveys. Mexico: Siglo XXI Editores.

Kitschelt H (1988) Organization and strategy of Belgian and West German ecology parties: A new dynamic of party politics in Western Europe Comparative Politics 20 (2): 127-154.

Kitschelt H (1989) The Logics of Party Formation: Ecological Politics in Belgium and West Germany. Ithaca, N.Y.: Cornell University Press.

Kitschelt H (1990) The medium is the message: Democracy and oligarchy in Belgian ecology parties In: Rüdig W (ed.) Green Politics One. Edinburgh: Edinburgh University Press, pp. 82-114. 
Kitschelt H and Hellemans S (1990) Beyond the European Left: Ideology and Political Action in the Belgian Ecology Parties. Durham, NC: Duke University Press.

Lowe PD. and Rüdig W (1986) Political ecology and the social sciences - the state of the art, British Journal of Political Science 16 (4): 513-550.

Mair P and Mudde C (1998) The party family and its study Annual Review of Political Science 1: 211-229.

McKenzie R (1982) Power in the Labour Party: the issue of intra-party democracy In: Kavanagh D (ed) The Politics of the Labour Party. London: George Allen \& Unwin, pp. 191-201.

Michels R (1911) Zur Soziologie des Parteiwesens in der modernen Demokratie.

Untersuchungen über die oligarchischen Tendenzen im Gruppenleben. Leipzig: Verlag von Dr. Werner Klinkhardt.

Miragliotta N (2015) Minor organizational change in green parties: An Australian case study Party Politics 21 (5): 699-711.

Müller-Rommel F (ed) (1989) New Politics in Western Europe: The Rise and Success of Green Parties and Alternative Lists. Boulder, CO: Westview Press. 
Müller-Rommel F (2002) The lifespan and the political performance of green parties in Western Europe In: Müller-Rommel F and Poguntke T (eds) Green Parties in National Governments. London: Frank Cass, pp. 1-16.

O’Neill M (1997) Green Parties and Political Change in Contemporary Europe: New Politics, Old Predicaments. Aldershot: Ashgate.

Ostrogorski M (1902) Democracy and the Organization of Political Parties. London: Macmillan and Co.

Panebianco A (1988) Political Parties: Organization and Power. Cambridge: Cambridge University Press.

Parkin S (1989) Green Parties: An International Guide London: Heretic Books.

Pedersen MN (1982) Towards a new typology of party lifespans and minor parties Scandinavian Political Studies 5 (1):1-16.

Pedersen MN (1991) The birth, life and death of small parties in Danish politics In: Müller-Rommel F and Pridham G (eds) Small Parties in Western Europe. Comparative and National Perspectives. London: Sage, pp. 95-114.

Poguntke T (1993) Alternative Politics: The German Green Party. Edinburgh: Edinburgh University Press. 
Poguntke T Scarrow SE and Webb PD (2016) Party rules, party resources and the politics of parliamentary democracies: How parties organize in the $21^{\text {st }}$ century Party Politics 22 (6): 661-678.

Raschke J (2001) Die Zukunft der Grünen. Frankfurt/Main: Campus.

Richardson D and Rootes C (eds.) (1995) The Green Challenge: The Development of Green Parties in Europe. London: Routledge.

Rihoux B (2001) Les partis politiques: Organisations en changement. Le test des ecologistes. Paris: L’Harmattan.

Rihoux B (2006) Governmental participation and the organisational adaption of green parties: On access, slack, overload and distress European Journal of Political Research 45 (supplement 1): S69-S98.

Rihoux B (2016) Green party organisations: The difficult path from amateur-activist to professional-electoral logics In: Van Haute E (ed) Green Parties in Europe. Abington: Routledge, pp. 298-314.

Rihoux B and Frankland EG (2008) Conclusion: The metamorphosis of amateur-activist newborns into professional-activist centaurs In: Frankland EG Lucardie P and Rihoux B (eds) Green Parties in Transition:The End of Grass-roots Democracy? Farnham, Surrey: Ashgate, pp. 259-287. 
Rüdig W (1990) Explaining green party development: reflections on a theoretical framework Strathclyde Papers on Government and Politics, 71.

Rüdig W (2008) Green party organization in Britain: Change and continuity In: Frankland, EG Lucardie P and Rihoux B (eds) Green Parties in Transition: The End of Grass-roots Democracy? Farnham, Surrey: Ashgate, pp. 199-223.

Sarkar S (1994) Green-Alternative Politics in West Germany, Vol. II: The Greens (Tokyo: United Nations University Press).

Scarrow SE (1999) Parties and the expansion of direct democracy Party Politics 5 (3): 341-363.

Seyd P (1999) New parties/new politics? A case study of the British Labour Party Party Politics 5 (3): 383-405.

Tan AC (1998) The impacts of party membership size: A cross-national comparison Journal of Politics 60 (1): 188-198.

Transparency International (2002) 'Corruption Perception Index 2002', https://www.transparency.org/research/cpi/cpi_2002/0/ [accessed 2 June 2017]

Young L and Cross W (2002) The rise of plebiscitary democracy in Canadian political parties Party Politics 8 (6): 673-699. 
Figure 1:

Predicted values for Party Lifespan (Fixed Effects)

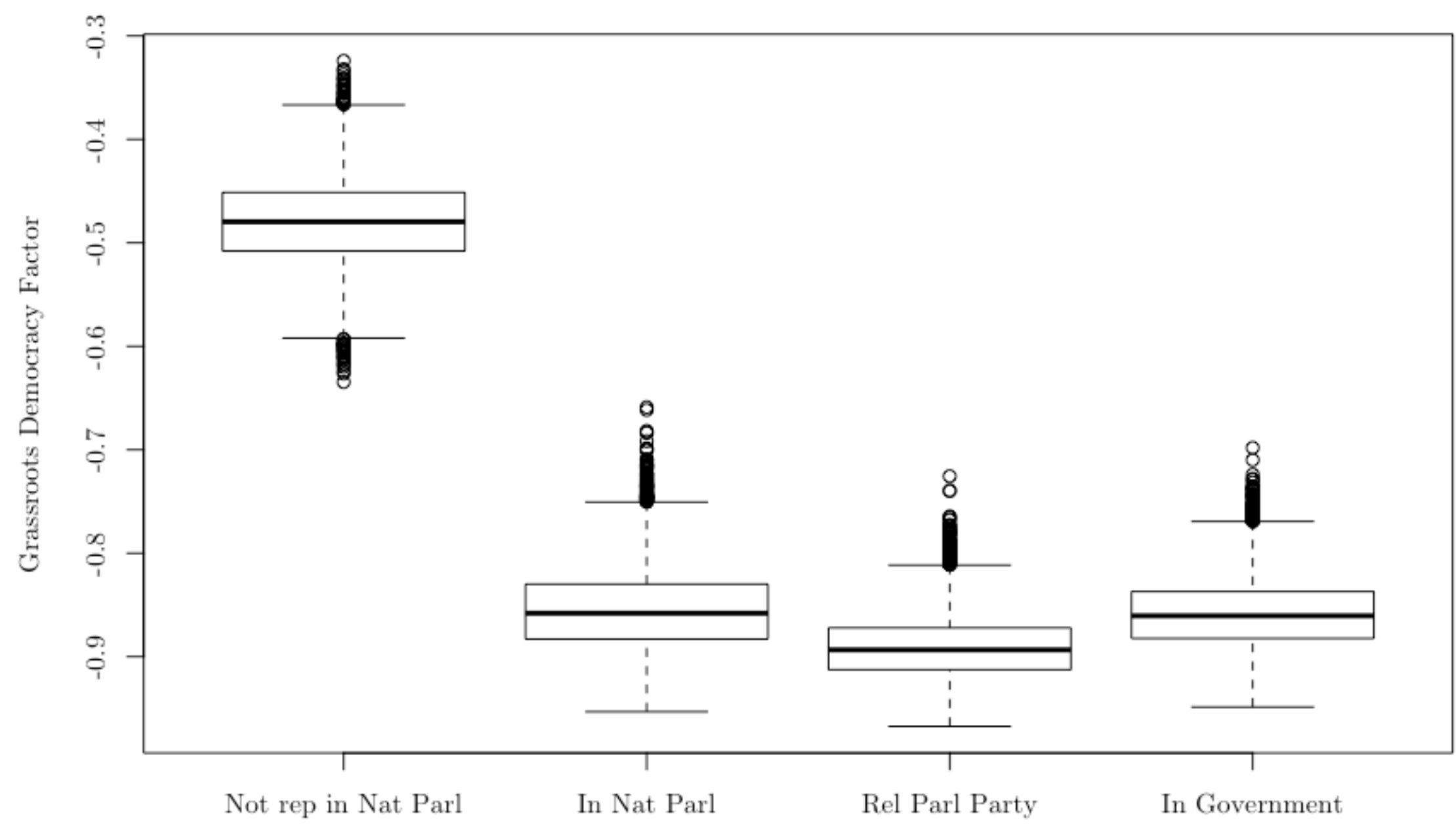

Lifespan Stages 
Table 1: Multi-level model of Support for Grassroots Democracy

Predictors

\section{Individual-level Variables}

\section{Social Movements}

Involvement in social movements 1960s-1990s

Involvment in social movements

2000s

$(0.01)$

$(0.01)$

\section{(Cross-sectional)}

Model 1

Model 2

(Multi-level)

$\begin{array}{ll}0.01 & 0.00 \\ (0.00) & (0.00)\end{array}$

\section{Ideology}

Left-wing

$0.11 * * *$

(0.01)

$0.09 * * *$

$0.19 * * *$

(0.01)

$0.13 * * *$

(0.01)

\section{Party Socialisation}

Party office holder

$\begin{array}{ll}0.04 & 0.05 \\ (0.03) & (0.03)\end{array}$

Public office holder

$\begin{array}{ll}-0.08 * & -0.08 * \\ (0.04) & (0.03)\end{array}$

\section{Demographics}

Age

$\begin{array}{ll}0.01 * * * & 0.01 * * * \\ (0.00) & (0.00)\end{array}$

Gender (female)

0.01

(0.03)
$0.12 * * *$

(0.02) 


\section{Party Level Predictors}

Latin/Greek political culture

$0.80 * * *$

(0.10)

Party Lifespan

(Reference: Party without Parliamentary

Representation)

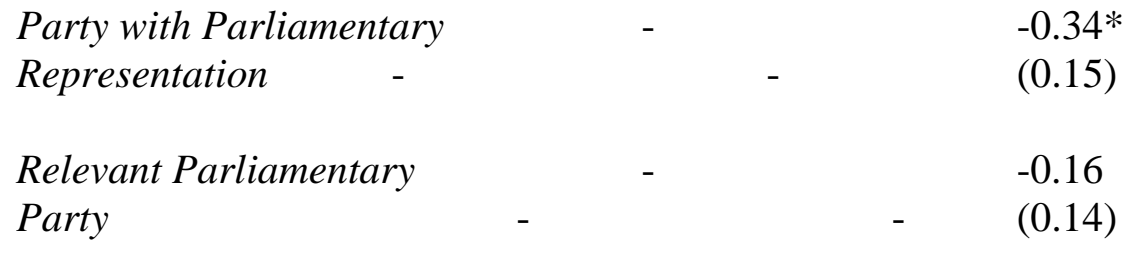

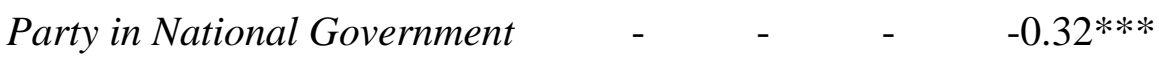

Intercept

$-1.97 * * *$

(0.08)

$-1.46 * * *$

$(0.13)$

R2

$\mathrm{BIC}$

Log Likelihood

Number of groups: Party

$\mathrm{N}$

5292

0.15

$14335.01 \quad 13558.16$

$-\quad-6714.78$

15

5292

Tests of statistical significance: $* * * \mathrm{p}<0.001 ; * * \mathrm{p}<0.01 ; * \mathrm{p}<0.05$ 
Appendix 1: Green Party Membership Survey 2002-2003

\begin{tabular}{|c|c|c|c|c|c|}
\hline Country & Party & $\begin{array}{l}\text { Total } \\
\text { Membership }\end{array}$ & $\begin{array}{l}\text { Questionnaires } \\
\text { Mailed }\end{array}$ & Valid Responses & $\begin{array}{l}\text { Response } \\
\text { Rate (Gross) } \\
\%\end{array}$ \\
\hline Australia & NSW Greens & 2400 & 2400 & 806 & 33.6 \\
\hline Austria & Die Grünen & 1714 & 1714 & 572 & 33.4 \\
\hline \multirow[t]{2}{*}{ Belgium } & AGALEV & 6000 & 500 & 279 & 55.8 \\
\hline & ECOLO & 4000 & 500 & 265 & 53.0 \\
\hline Finland & Vihreä Liitto & 1650 & 825 & 397 & 48.1 \\
\hline France & Les Verts & 9000 & 3000 & 1209 & 40.3 \\
\hline Germany & Bündnis ‘90/Die Grünen & 45000 & 2201 & 1085 & 49.3 \\
\hline Greece & 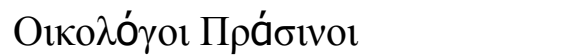 & 129 & 129 & 31 & 24.0 \\
\hline Italy & Federazione dei Verdi & 20000 & 999 & 291 & 29.1 \\
\hline Ireland & Green Party/Comhaontas Glas & 650 & 650 & 294 & 45.2 \\
\hline Netherlands & GroenLinks & 15000 & 500 & 251 & 50.2 \\
\hline New Zealand & Green Party of Aotearoa & 4067 & 1000 & 520 & 52.0 \\
\hline Norway & De Grønne & 500 & 500 & 186 & 37.2 \\
\hline \multirow[t]{2}{*}{ Spain } & Los Verdes de Andalucia & 400 & 400 & 73 & 18.3 \\
\hline & Els Verds del Pais Valencia & 100 & 100 & 38 & 38.0 \\
\hline Sweden & Miljöpartiet De Gröna & 8000 & 500 & 255 & 51.0 \\
\hline \multirow[t]{2}{*}{ UK } & Green Party of England \& Wales & 4000 & 2334 & 1297 & 55.6 \\
\hline & Scottish Green Party & 517 & 517 & 260 & 50.3 \\
\hline TOTAL & & 123,160 & 18,769 & 8,109 & 43.2 \\
\hline
\end{tabular}




\title{
Appendix 2: Question Wordings
}

\section{$\underline{\text { Dependent Variable }}$}

Q. Here are a number of organisational principles that some have associated with the concept of 'grassroots democracy'. To what extent do you agree or disagree that these principles should be adopted (or retained) by the Green Party?

(Strongly disagree, Disagree, Neither agree or disagree, Agree or Strongly Agree, 1- 5)

No individual members should be able to retain a national party office for more than three years consecutively.

Green members of parliament should not be able to hold any party office.

Green members of parliament should only be allowed to earn up to the average national wage, the rest of their income should be donated to the party.

Q. 'Established' political parties normally have ONE leader. Do you think the Green Party should have one leader? Yes / No

Dependent Variable: Factor scores of these four statements, ,leadership variable recoced 1 Yes 5 No

\section{Independent Variables}

\section{Social Movements}

Q. Below is a list of various social movements. Have you ever been active in any of them (e.g. taken part in demonstrations, organised meetings etc)? If yes, please indicate in which decades you have been active.

(Never active, or active in: 1960s, 1970s, 1980s, 1990s, 2000s)

\author{
Student Movement \\ Environmental Movement \\ Animal Rights Movement \\ Anti-nuclear (energy) Movement \\ Peace Movement \\ Feminist Movement \\ Gay and Lesbian Rights Movement \\ Labour/Trade Union Movement \\ Third World Solidarity Movement \\ Anti-Globalisation Movement
}




\section{Ideology}

Q. In politics people sometimes talk of left and right. Where would you place the following political parties on the scale below where 0 is the most left-wing position and 10 is the most right-wing? And where would you place YOURSELF on the scale below?

Scale 0 Left 010 Right (recoded 0 Right to 10 Left)

Q. How much do you agree or disagree with each of these statements?

(Strongly disagree, Disagree, Neither agree or disagree, Agree or Strongly Agree, 1- 5)

War is always wrong

\section{Party Socialisation}

Q. Do you currently hold any office within the party (e.g. local party spokesperson) or any public office representing the party (e.g. local councillor)?

- Party office Yes/No

- Public office Yes/No

\section{Demographics}

Q. In which year were you born?

(Recoded as Age: Year of survey - year of birth)

Q. Are you male or female? Male/Female

\section{Party Lifespan}

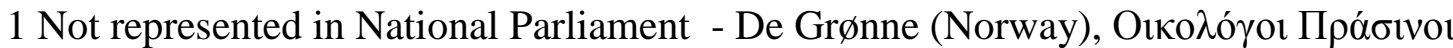
(Greece); Green Party of England \& Wales, Scottish Green Party

2 Represented in National Parliament - Green Party -Comhaontas Glas (Republic of Ireland), Els Verds del Pais Valencia (Spain), Los Verdes de Andalucia (Spain)

3 "Relevant" Party Represented in Parliament but not in Government - GroenLinks (The Netherland), Miljöpartiet - De Gröna (Sweden), Green Party of Aotearoa New Zealand 4 In Government at national level - Bündnis '90 / Die Grünen (Germany), AGALEV and ECOLO (Belgium), Les Verts (France), Federazione dei Verdi (Italy), Vihreä Liitto (Finland)

\section{Latin/Greek}

0 De Grønne (Norway), Green Party of England \& Wales, Scottish Green Party, Comhaontas Glas (Republic of Ireland), GroenLinks (The Netherlands), Miljöpartiet - De Gröna (Sweden), Green Party of Aotearoa New Zealand, Bündnis '90 / Die Grünen (Germany), AGALEV (Belgium), Vihreä Liitto (Finland) 


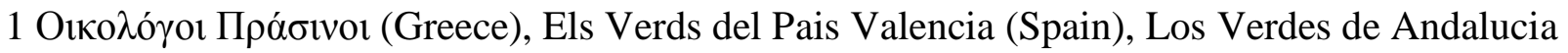
(Spain), ECOLO (Belgium), Les Verts (France), Federazione dei Verdi (Italy) 
Appendix 3: Indicators of 'Grassroots Democracy' (\% Agree or Strongly Agree and \% "No" to a Single Party Leader)

\begin{tabular}{|c|c|c|c|c|c|c|c|c|}
\hline \multirow[t]{2}{*}{ Country } & \multirow[t]{2}{*}{ Party } & \multirow[t]{2}{*}{$\begin{array}{l}\text { Term limits } \\
\text { of } 3 \text { years }\end{array}$} & \multirow{2}{*}{$\begin{array}{l}\text { Incompatibility of } \\
\text { party and public } \\
\text { office }\end{array}$} & \multirow{2}{*}{$\begin{array}{l}\text { Parliamentarians' } \\
\text { income should be } \\
\text { limited }\end{array}$} & \multirow{2}{*}{$\begin{array}{l}\text { Opposition } \\
\text { to Single } \\
\text { Party Leader }\end{array}$} & \multicolumn{2}{|c|}{$\begin{array}{l}\text { Grassroots Democracy index } \\
\text { (factor scores) }\end{array}$} & \multirow[t]{2}{*}{$\mathrm{N}$ (valid) } \\
\hline & & & & & & Mean & Std. Dev. & \\
\hline Belgium & AGALEV & 13 & 29 & 20 & 20 & -0.43 & 0.73 & 261 \\
\hline Belgium & ECOLO & 55 & 54 & 36 & 85 & 0.61 & 0.9 & 252 \\
\hline Finland & Vihreä Liitto & 28 & 20 & 33 & 15 & -0.38 & 0.84 & 382 \\
\hline France & Les Verts & 64 & 51 & 44 & 78 & 0.77 & 0.88 & 1123 \\
\hline Germany & $\begin{array}{l}\text { Bündnis '90 / } \\
\text { Die Grünen }\end{array}$ & 15 & 34 & 22 & 63 & -0.51 & 1.06 & 1052 \\
\hline Greece & 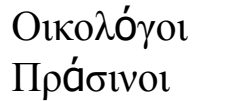 & 65 & 57 & 69 & 100 & 0.99 & 0.86 & 28 \\
\hline Italy & $\begin{array}{l}\text { Federazione } \\
\text { dei Verdi }\end{array}$ & 51 & 44 & 48 & 47 & 0.39 & 0.91 & 280 \\
\hline $\begin{array}{l}\text { New } \\
\text { Zealand }\end{array}$ & $\begin{array}{l}\text { Green Party } \\
\text { of Aotearoa } \\
\text { New Zealand } \\
\end{array}$ & 13 & 33 & 15 & 90 & -0.13 & 0.7 & 488 \\
\hline Norway & De Grønne & 26 & 41 & 44 & 45 & 0.04 & 0.89 & 175 \\
\hline $\begin{array}{l}\text { Republic of } \\
\text { Ireland }\end{array}$ & $\begin{array}{l}\text { Green Party - } \\
\text { Comhaontas } \\
\text { Glas }\end{array}$ & 42 & 25 & 26 & 18 & -0.22 & 0.88 & 275 \\
\hline Spain & $\begin{array}{l}\text { Els Verds del } \\
\text { Pais } \\
\text { Valencia }\end{array}$ & 53 & 60 & 49 & 67 & 0.57 & 1.01 & 34 \\
\hline Spain & $\begin{array}{l}\text { Los Verdes } \\
\text { de Andalucia }\end{array}$ & 39 & 57 & 42 & 38 & 0.29 & 0.96 & 72 \\
\hline Sweden & $\begin{array}{l}\text { Miljöpartiet - } \\
\text { De Gröna }\end{array}$ & 22 & 23 & 26 & 55 & -0.28 & 0.93 & 224 \\
\hline
\end{tabular}




\begin{tabular}{|l|l|c|c|c|c|c|c|c|}
\hline $\begin{array}{l}\text { The } \\
\text { Netherlands }\end{array}$ & GroenLinks & 18 & 75 & 22 & 18 & -0.14 & 0.67 & 237 \\
\hline UK & $\begin{array}{l}\text { Green Party } \\
\text { of England \& } \\
\text { Wales** }\end{array}$ & 30 & 20 & 28 & 48 & -0.11 & 0.85 & $988^{* *}$ \\
\hline UK & $\begin{array}{l}\text { Scottish } \\
\text { Green Party }\end{array}$ & 31 & 23 & 30 & 45 & -0.18 & 0.87 & 230 \\
\hline ALL*** & & 37 & 39 & 27 & 50 & 0.005 & 1.00 & 6101 \\
\hline
\end{tabular}

** Weighted to account for different sub-samples

*** Weighted according to party size (total membership) 


\section{Appendix 4: Robustness Checks}

The first robustness check consisted in bivariate models using each of the individual level variables. The results from Table A1 show that all variables are correlated with the dependent variable.

Table A1: Bivariate models of Grassroots Democracy (OLS - individual level)

\begin{tabular}{|c|c|c|c|c|c|c|c|c|}
\hline & $\begin{array}{l}\text { Model } \\
1\end{array}$ & $\begin{array}{l}\text { Model } \\
2\end{array}$ & $\begin{array}{l}\text { Model } \\
\mathbf{3} \\
\end{array}$ & $\begin{array}{l}\text { Model } \\
\mathbf{4} \\
\end{array}$ & $\begin{array}{l}\text { Model } \\
5 \\
\end{array}$ & Model 6 & $\begin{array}{l}\text { Model } \\
7\end{array}$ & $\begin{array}{l}\text { Model } \\
8\end{array}$ \\
\hline (Intercept) & $\begin{array}{l}- \\
0.16^{* * *} \\
(0.02)\end{array}$ & $\begin{array}{l}- \\
0.17^{* * *} \\
(0.02)\end{array}$ & $\begin{array}{l}- \\
1.11^{* * *} \\
(0.06)\end{array}$ & $\begin{array}{l}- \\
0.93^{* * *} \\
(0.04)\end{array}$ & $\begin{array}{l}-0.00 \\
(0.01)\end{array}$ & $\begin{array}{l}0.02 \\
(0.01)\end{array}$ & $\begin{array}{l}- \\
0.27^{* * *} \\
(0.05)\end{array}$ & $\begin{array}{l}-0.03 \\
(0.02)\end{array}$ \\
\hline
\end{tabular}

Involvement in

social movements

1960s-1990s

$0.04^{* * *}$

Involvment in

social movements

$(0.00)$

2000 s

$0.12^{* * *}$

(0.01)

Left-wing

$0.15^{* * *}$

(0.01)

Pacifist

(0.01)

Party Office

holder

$0.07^{*}$

(0.03)

Public office

holder

$-0.06$

(0.04)

Age

$0.01^{\text {*** }}$

(0.00)

Gender (Female)

$0.08^{* *}$

\begin{tabular}{lllllllll} 
& \multicolumn{1}{c}{$0.03)$} \\
\hline $\mathbf{R}^{\mathbf{2}}$ & 0.03 & 0.05 & 0.06 & 0.07 & 0.00 & 0.00 & 0.01 & 0.00 \\
Adj. R$^{\mathbf{2}}$ & 0.03 & 0.05 & 0.06 & 0.07 & 0.00 & 0.00 & 0.01 & 0.00 \\
Num. obs. & 6151 & 6151 & 5698 & 5974 & 5921 & 5921 & 6103 & 6101 \\
RMSE & 0.98 & 0.97 & 0.97 & 0.96 & 1.00 & 1.00 & 0.99 & 1.00 \\
\hline
\end{tabular}

**** $\mathrm{p}<0.001,{ }^{* *} \mathrm{p}<0.01,{ }^{*} \mathrm{p}<0.05$

We also tested the relationship by country (not only by party), allowing the intercept to vary by country. As we can see in Table A2, the results do not vary significantly. Furthermore, Figure A1 shows the varying intercepts show some significant differences, all in the expected direction 
Table A2: Model using varying intercepts by party

\begin{tabular}{|c|c|}
\hline & Model 1 \\
\hline (Intercept) & $\begin{array}{l}-1.49^{* * *} \\
(0.14)\end{array}$ \\
\hline Involvement in social movements & 0.00 \\
\hline $1960 s-1990 s$ & $(0.00)$ \\
\hline $\begin{array}{l}\text { Involvment in social movements } \\
2000 \mathrm{~s}\end{array}$ & $0.04^{* * *}$ \\
\hline & $(0.01)$ \\
\hline Left-wing & $\begin{array}{l}0.09^{* * *} \\
(0.01)\end{array}$ \\
\hline Pacifist & $\begin{array}{l}0.13^{* * *} \\
(0.01)\end{array}$ \\
\hline Party Office holder & $\begin{array}{l}0.05 \\
(0.03)\end{array}$ \\
\hline Public office holder & $\begin{array}{l}-0.08^{*} \\
(0.03)\end{array}$ \\
\hline Age & $\begin{array}{l}0.00^{* *} \\
(0.00)\end{array}$ \\
\hline Gender (Female) & $\begin{array}{l}0.12^{\text {**** }} \\
(0.02)\end{array}$ \\
\hline Latin/Greek political culture & $\begin{array}{l}0.95^{* * *} \\
(0.07)\end{array}$ \\
\hline Party with Parliamentary Representation & $\begin{array}{l}-0.35^{*} \\
(0.17)\end{array}$ \\
\hline Relevant Parliamentary Party & $\begin{array}{l}-0.13 \\
(0.15)\end{array}$ \\
\hline Party in National Government & $\begin{array}{l}-0.37^{* *} \\
(0.14)\end{array}$ \\
\hline $\mathrm{BIC}$ & 13559.54 \\
\hline Log Likelihood & -6715.46 \\
\hline Num. obs. & 5292 \\
\hline Num. groups: country & 13 \\
\hline Var: country (Intercept) & 0.03 \\
\hline Var: Residual & 0.73 \\
\hline
\end{tabular}

Figure A1: Varying intercepts by country 


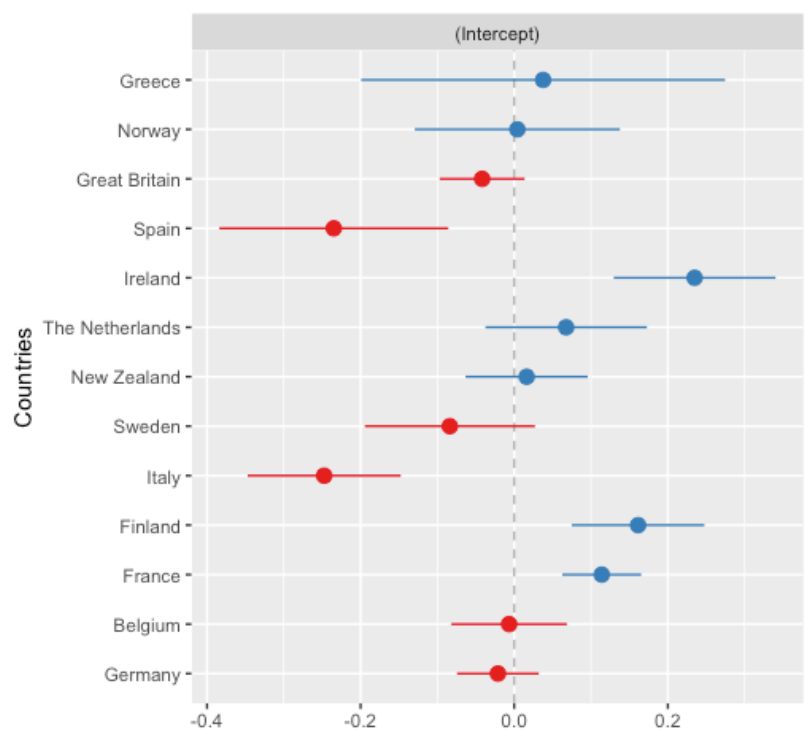


Finally, our last robustness check consisted in using the same model but with an additive scale as dependent variable. Our choice of factor analysis is mostly based on theory, but we show that our results hold even when we do not allow each item to load in a different way (Table A3).

Table A3: Model using the additive scale as dependent variable

\begin{tabular}{|c|c|}
\hline & Model 1 \\
\hline$\overline{\text { (Intercept) }}$ & $\begin{array}{l}2.66^{* * *} \\
(0.61)\end{array}$ \\
\hline Involvement in social movements & $0.04^{* *}$ \\
\hline $1960 s-1990 s$ & $(0.01)$ \\
\hline $\begin{array}{l}\text { Involvment in social movements } \\
2000 \mathrm{~s}\end{array}$ & $0.15^{* * *}$ \\
\hline & $(0.03)$ \\
\hline Left-wing & $\begin{array}{l}0.35^{\text {**** }} \\
(0.03)\end{array}$ \\
\hline Pacifist & $\begin{array}{l}0.45^{* * * *} \\
(0.04)\end{array}$ \\
\hline Party Office holder & $\begin{array}{l}0.19 \\
(0.11)\end{array}$ \\
\hline Public office holder & $\begin{array}{l}-0.17 \\
(0.12)\end{array}$ \\
\hline Age & $\begin{array}{l}0.00 \\
(0.00)\end{array}$ \\
\hline Gender (Female) & $\begin{array}{l}0.48^{* * * *} \\
(0.09)\end{array}$ \\
\hline Latin/Greek political culture & $\begin{array}{l}3.17^{\text {**** }} \\
(0.53)\end{array}$ \\
\hline Party with Parliamentary Representation & $\begin{array}{l}-2.03^{* *} \\
(0.77)\end{array}$ \\
\hline Relevant Parliamentary Party & $\begin{array}{l}-0.46 \\
(0.73)\end{array}$ \\
\hline Party in National Government & $\begin{array}{l}-1.47^{*} \\
(0.64) \\
\end{array}$ \\
\hline$\overline{\mathrm{AIC}}$ & 26899.42 \\
\hline BIC & 26998.03 \\
\hline Log Likelihood & -13434.71 \\
\hline Num. obs. & 5292 \\
\hline Num. groups: party & 15 \\
\hline Var: party (Intercept) & 0.70 \\
\hline Var: Residual & 9.27 \\
\hline
\end{tabular}

*** $\mathrm{p}<0.001,{ }^{* *} \mathrm{p}<0.01,{ }^{*} \mathrm{p}<0.05$ 


\section{NOTES}

${ }^{1}$ We are grateful to E. Gene Frankland and Robert Johns for comments on a previous version of this paper. All
shortcomings remain our own responsibility, of course.
${ }^{2}$ The project 'European Green Party Members' set out to collect data on green party members across Western Europe, using a 'common core questionnaire' mailed to random samples of members during 2002 and 2003 . It was funded by the British Academy under its Large Research Grant programme (LRG-31746) and directed by Wolfgang Rüdig (University of Strathclyde). Additional support was provided by the Research Development Fund of the University of Strathclyde. The financial support of the British Academy and the University of Strathclyde is gratefully acknowledged.

Individual national surveys were carried out under the responsibility of the following researchers, often with additional financial support from their home institutions: Australia: Ariadne Vromen (University of Sydney); Austria: Wolfgang C. Müller (University of Mannheim); Belgium (AGALEV): Jo Buelens (Free University Brussels);Belgium (ECOLO): Benoît Rihoux (Catholic University of Louvain); Finland: Jukka Paastela (University of Tampere); France: Daniel Boy (CEVIPOF, Paris) and Benoît Rihoux (Catholic University of Louvain); Germany: Wolfgang Rüdig (University of Strathclyde); Greece: Iosif Botetzagias (Technological Institute of the Ionian Islands); Republic of Ireland: John Garry (Queen's University Belfast); Italy: Roberto Biorcio (Bicocca University, Milan); the Netherlands (Groen-Links): Paul Lucardie and Wijbrandt van Schuur (University of Groningen); New Zealand: Tim Bale (Sussex University); Norway: Gunnar Grendstad (University of Bergen); Spain: Luis Ramiro (University of Murcia); Sweden: Anders Widfeldt (University of Aberdeen); UK (England \&Wales): Wolfgang Rüdig (University of Strathclyde); UK (Scotland): Lynn Bennie (University of Aberdeen).

${ }^{3}$ We also considered alternative variables. Many analyses of the development of green parties relied on Ronald Inglehart's theory of post-materialist value change (Inglehart 1977, 1990). The fact that most green parties did not simply limit themselves to an environmental agenda but espoused a far larger agenda of 'New Left' issues was a key indicator of their 'post-materialist' nature: the adherence to grass-roots democracy was one aspect of their postmaterialist 'New Politics' character (Poguntke 1993, p. 137), and thus 'post-materialists' could be expected to be more sympathetic to grassroots democracy. A further possible approach is the idea of the 'new environmental paradigm' (NEP) first formulated by Riley Dunlap and Kent van Liere (1978). The basic idea is that ecologists have embraced a radically new ideology that is essentially characterised by a rejection of the dominant industrial paradigm. By extension, greens as representatives of the ecological movement could be expected to be associated with this new paradigm, and thus members scoring highly on NEP measurements could expected to support grassroots democracy.

We excluded both variables on empirical as well as theoretical grounds. The theory of post-materialist value change was originally developed to explain the up-rise of student movements in the 1960s: while there are clear links between this phenomenon and green parties, the key elements of the post-materialism theory are not specifically geared towards the key green political identities. The theory essentially assumes that the key demands of greens on environmental and other policy issues are subservient to their alleged main identity understood to centre around 'post-materialist' values (Lowe and Rüdig 1986; Rüdig 1990). The theory of the 'new environmental paradigm' also was developed in response to an earlier debate, namely the rise of the 'anti-growth' ecology movement of the late 1960s and early 1970s. The strong focus of the theory on the question of growth might have been crucial in the early 1970s but had arguably lost its identity-giving character by the late 1970s/early 1980s.

The alternative was to rely on variables that focus specifically on the key green identities as understood by greens at the time of party formation. Perhaps the most important issues in most countries were nuclear power and nuclear weapons, and thus a strong anti-nuclear and pacifist orientation could be central to green identity. Empirically, post-materialism and NEP were predictors of support for grassroots democracy but their effect was quite minor, and thus we decided to remove both variables from the final model.

${ }^{4}$ The project is fully documented, with access to all questionnaires used, at the project website http://www.egpm.eu

${ }^{5}$ One important study touching on related issues is Kitschelt's analysis of Belgian green party members' perception of the importance of various obstacles to achieving internal party democracy as proposed by Michels (Kitschelt 1990).

${ }^{6}$ Unfortunately, the funding available only covered the cost of fielding one round of questionnaires: there was thus no possibility to discuss specific question wordings with party activists and conduct pre-tests in each country. However, all members of the team were experienced researchers with a long record of research on green parties in their respective countries. The involvement of the leading country experts on green party politics should thus provide some insurance that questions posed were not inappropriate in a specific national context. 
${ }^{7}$ Questions asking member about their attitudes to the three issues were to be used in all national surveys but were not fielded in Australia and only one question was included in the Austrian questionnaire. Australia and Austria are thus not part of the multi-variate analysis presented here.

${ }^{8}$ Among the variables we considered was party size as smaller parties might be expected to be more open to internal party democracy (cf. Tan 1998). We also considered the effect of parties having adopted certain measures of grassroots democracy or not. In particular the issue of 'collective leadership' was important here as some green parties, namely in Finland, Italy, the Netherlands, the Republic of Ireland, and Spain (Andalucia), had in 2002 adopted 'single leaders'. In 2003, the green party of Flanders, renamed Groen!, adopted the 'single leader' concept (Buelens and Delwit 2008, p. 88), followed in 2007 by the Green Party of England \& Wales (Rüdig 2008, p. 214). At the bivariate level, we do find that support for grassroots democracy is higher among parties with a smaller membership, and that support for 'single leaders' is higher in parties that have adopted single leaders. However, we decided not to include these variables as a way to ensure parsimonious modelling. Furthermore, most of the unobserved variation between parties should be controlled for by using varying intercepts.

${ }^{9}$ The only previous systematic comparison of attitudes of AGALEV and ECOLO members conducted by Herbert Kitschelt focuses on the influence of 'cleavage mobilisation'. Kitschelt found that AGALEV had more 'ideologues' as there was a higher degree of social movement mobilisation in Flanders than in Wallonia (Kitschelt and Hellemans 1990, p. 195) which in turn was seen as the reason why AGALEV members blamed 'party leaders' for the lack of internal party democracy to a much higher degree than ECOLO members (Kitschelt 1990, p. 104). The theory of 'cleavage mobilisation' would suggest that support for grassroots democracy should be higher among AGALEV members, but by 2002, the relative position of AGALEV and ECOLO members appear to be reversed, and ECOLO members are clearly more supportive of key elements of grassroots democracy. 